\title{
3D Reconstruction of a Roman Bridge in Canosa di Puglia (Italy)
}

\author{
GERMANO GERMANO', University of Naples Federico II, Italy
}

\begin{abstract}
The Roman bridge near Canosa di Puglia (Southern Italy) currently has a very different morphology from the one planned by its builders in the second century $A D$ as part of the program for the construction of the Via Traiana. Although the piers, the abutments, and the foundation platea are still preserved from the Roman age, the changes made over the centuries have altered its aspect, leaving only traces of its monumental past. Starting from the surviving elements and the few available sources, an investigation has been carried out to reconstruct its original structure, thanks to a multidisciplinary and metrological approach and the combined use of aerophotogrammetry and 3D modeling. The use of these technologies proved to be an essential tool, since they made it possible to carry out a survey otherwise hampered by the bulk of the artifact and the presence of the Ofanto River flowing below. The outcome of this research has led to a reconstruction hypothesis that makes it possible to visualize a majestic monument that deserves to take its rightful place in the repertoire of Roman architecture.
\end{abstract}

\section{Keywords:}

3D reconstruction, Bridge, Roman Architecture, Via Traiana.

\section{SDH Reference:}

G. Germano'. 2021. 3D reconstruction of a Roman Bridge in Canosa di Puglia (Italy). SDH, 5, 1, 75-87.

https://doi.org/10.14434/sdh.v5i1.30812

\section{INTRODUCTION}

The graphic representation of architecture has always been a valid method of preservation that has made it possible to transmit architectural and archaeological heritage even when a monument has been lost or destroyed. Until the advent of computers, the methods of representation were strongly limited from the observer's point of view and often returned only a partial image of the contexts they described, not to mention the vulnerability of their support. It is enough to think of the Forma Urbis of the Severan age, which came to us in a fragmentary condition, the drawings of travelers like Ciriaco d'Ancona, schematic and not entirely faithful to the original proportions, down to the more recent surveys which, although accurate in their measurements and in the quantity of points of view, do not always give all the information necessary for understanding the monument. As Alexandrian scholars did with ancient texts, these representations of monuments, whether consciously or not,

\footnotetext{
The work for this article has been carried out in the postgraduate thesis project in Architectural Heritage and Landscape entitled "Il ponte romano sull'Ofanto: analisi delle tecniche costruttive, ipotesi di restituzione e valorizzazione".

Author's address: Germano Germano', Scuola Superiore Meridionale, Università di Napoli Federico II, Largo San Marcellino 10, 80138, Napoli, Italy; email: germano.germano@live.com

(C) 2021 by the author; licensee Studies in Digital Heritage, IU, Bloomington (IN), USA. This article is an open access article distributed under the terms and conditions of the Creative Commons Attribution License (CC BY-NC)
} 
make a choice that inevitably sacrifices parts of a context that is sometimes indecipherable to us or, in its shortcomings, even misunderstood.

In contexts that are difficult to access or of great extension, the univocal understanding of the elements is necessary and does not admit partial data on pain of interpretative distortion.

The diffusion of new digital technology and the constant decrease of its cost have made it possible to develop methodologies able to detect, interpret and preserve very important data regarding works of archaeological and architectural heritage [McCarthy 2014, Stylianidis 2020]. An interesting case study is the one related to the Roman bridge over the Ofanto river near the city of Canosa di Puglia, in Southern Italy, whose survey and digitalization were possible thanks to the combined use of photogrammetry and 3D modeling. The purpose of this paper is to describe the process of data collection by means of these technologies and to point out their importance in the interpretation of the monument in order to propose a reconstruction hypothesis about the original appearance of the structure in Roman times.

\section{THE BRIDGE}

\subsection{Structure}

Today the dimensions of the bridge (Fig. 1) are $170 \mathrm{~m}$ long and $4.5 \mathrm{~m}$ wide with five arches of different morphologies and sizes (starting from the east: $6.50 \mathrm{~m}, 13 \mathrm{~m}, 12.10 \mathrm{~m}, 12.10 \mathrm{~m}, 13 \mathrm{~m}$ ) supported on four piers of different sizes, ranging from a minimum of $6.2 \mathrm{~m}$ to a maximum of $8.4 \mathrm{~m}$. These are composed of square ashlars of equal size and equipped with triangular starlings and pyramidal cones, upstream and downstream. The only remains of the original structure are the piers (Fig. 1), the abutments, and the foundation platea [Cassano 1992], and it is on the basis of these elements, combined with the few documents available, that we attempted to reconstruct its original facies.

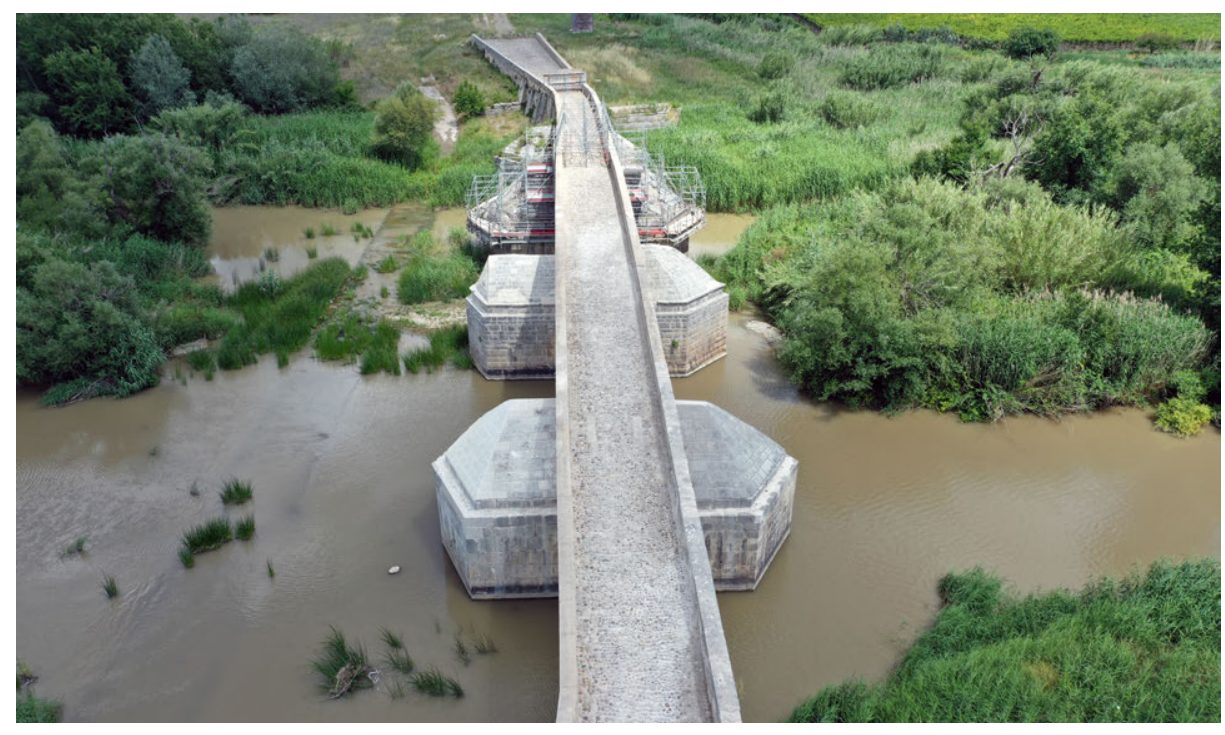

Figure 1. The bridge of Canosa di Puglia. View from West. 


\subsection{History}

The bridge was located along the Via Traiana, a faster alternative to the Via Appia, from which it departed from the city of Benevento and was built by Emperor Trajan in 109 AD to connect Rome to Brindisi, the main port to the East. The original structure therefore dates back to that period, although we cannot exclude the presence of an earlier bridge, since another road called Via Minucia [Ceraudo 2008] previously ran along the same route.

In ancient times, its usefulness must have been fundamental for the passage through that territory, since the Ofanto river presented a wide obstacle to overland travel.

In the Middle Ages the same route as the Via Traiana was followed by the Via Francigena, a road over which Christian pilgrims from all over Europe reached the ports of Apulia to the Holy Land, and later by the routes called tratturi (drover's roads), used by shepherds on their transhumance routes from Central Italy to the Apulian plains.

Although numerous restorations are attested during the reigns of Septimius Severus, Caracalla, the Tetrarchs and Constantine [Chelotti et al. 1990] and perhaps in the 16th century [Ieva 2015], the bridge was preserved as a structure with a large central arch until the $18^{\text {th }}$ century. In some older cadasters preserved in the State Archives of Foggia, it is schematically represented with three arches. The same is true in the only document drawn up with more precision on the occasion of a technical survey that became necessary because of worrying signs of the structure's potential failure. A drawing (Fig. 2) made by Francesco Delfino in 1749 [Tritto 2005] clearly shows a bridge with a donkeyback profile, characterized by a large central arch and two smaller lateral ones supporting a structure made of large stone blocks. Even if it is a schematization, the drawing confirms the original configuration and is accompanied by a text that shows the exact measurements of the arches.

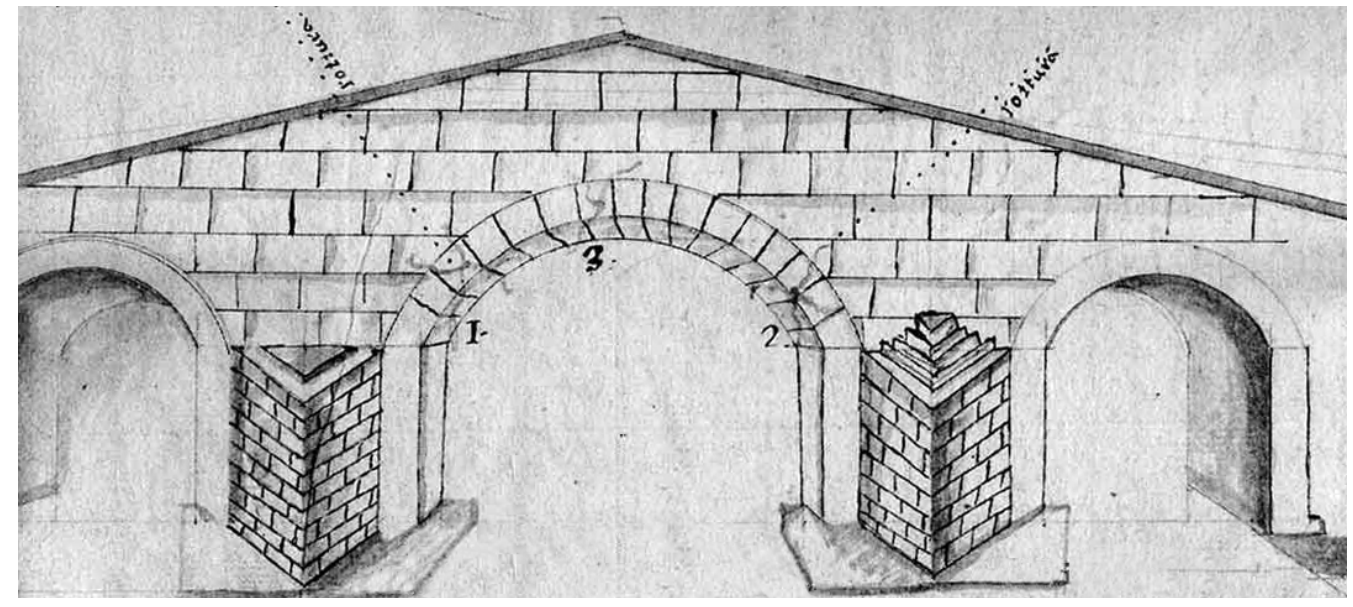

Figure 2. Drawing of the bridge by Francesco Delfino, 1749, showing its aspect before the collapse of 1751. (State Archives of Foggia, Italy)

On February 11th, 1751 the central arch collapsed, and the technicians involved in the discussion about its reconstruction opted for a more statically secure choice: they introduced a new central pier from which two new arches were added in place of the central one, strongly altering the design of 
the previous structure. From this moment on, the memory of the magnificence of the ancient monument was slowly lost, further compromised during the Second World War by retreating troops who bombed the bridge and opened a breach in the flood containment walls to build a reinforced concrete walkway over the foundation platea, destroying forever all material evidence of most of the elements that made it up and reducing the utility of the structure in case of flood.

Following its reconstruction, vehicular traffic was moved a few hundred meters farther north on a new road, and a new bridge was built, less grandiose than its neighbor, to adapt to the new requirements. As it was no longer frequented, the decline of the ancient bridge became inexorable until its recent rediscovery which, however, did not fully exhaust its valorization.

\subsection{Prospects}

It is in this context of rediscovery that we undertook the present project of analysis and 3D reconstruction of the architectural monument. In particular, we mapped the different USM (Italian for Masonry (or Structural) Stratigraphic Units [Parenti 1988, Fenthress and Goodson 2003]) and sought to understand the different construction phases. The result is a model that leaves room for future developments in research and possible future discoveries. Ideally, the model will also serve to highlight the importance of the bridge within the archaeological and architectural context not only of the territory of Canosa di Puglia, already rich in evidence of the Roman past, but of Roman architecture and ancient construction techniques more generally.

\section{METHODOLOGY}

\subsection{Sources and metrological approach}

First of all, we proceeded to study all the written sources concerning the bridge and its history, collecting the original documents preserved in the State Archives of Foggia and the texts relating to the only archaeological excavations conducted on the site [Cassano 1986, Cassano 1992], mainly aimed at studying the foundation platea. A substantial lack of homogeneity in the history of the studies has emerged, owing to the different points of view of each discipline involved (history, archaeology, restoration). As a result, even if the elements of the puzzle were all present and emerged in the various investigations, they were never related to each other in an all-encompassing multidisciplinary approach. To develop the reconstruction hypothesis, we took into account the information contained in two reports dating to 1584 and 1749, which indicated the measurements of the bridge. In the first [Ieva 2015] a measurement of 128 palms in length and 40 in height is reported for the central arch. The second, contained in Francesco Delfino's technical report [Tritto 2005], describes the bridge as follows: "[...] the main arch (is) 112 palms wide, from the floor to the top (of) 44 palms high, with a front of 5 palms, (while) the two lateral arches are wide 50 palms each, and 25 palms high [...]". The name used for the unit of measurement in question, i.e., the palm, is not immediately referable to a precise numerical value, since anthropometric measurements took different values depending on the historical and geographical context of reference.

Before the unification of Italy, these differences generated great confusion in the conversion of measurements. In our case, since both sources were local, it must be imagined that they used the 
measurement system of the reference context to which Canosa belonged, i.e., the Kingdom of Naples, which included the whole of Southern Italy. In some texts [Tritto 2005] this value is reported as corresponding to $0.26455 \mathrm{~m}$. Researching the subject, we found that in reality this correspondence is valid only starting from 1840, while at the time of the two reports (1584 and 1749), there was a different measure of the Neapolitan palm, regulated by an edict issued on 6 April 1480 by Ferdinand I of Aragon and equal to $0.26367 \mathrm{~m}$ [Salvati 1970]. This clarification is necessary although it may appear to be incidental, since the margin of error may be considerable, as these are large lengths. The purpose of this first survey was to collect the size data reported in the most recent source (1749) and compare it to the decimal metric system. (Table 1):

Table 1. Conversion chart (Neapolitan palms)

\begin{tabular}{|c|c|c|}
\hline Element & $\begin{array}{c}\text { Neapolitan palms } \\
(0.26367 \mathrm{~m})\end{array}$ & Meters \\
\hline Main arch (span) & 112 & 29.53 \\
\hline Main arch (height) & 44 & 11.6 \\
\hline Lateral arch (span) & 50 & 13.19 \\
\hline Lateral arch (height) & 25 & 6.59 \\
\hline Front (parapet?) & 5 & 1.31 \\
\hline
\end{tabular}

Subsequently, we converted the same measurements into Roman feet (1 Roman foot $=0.296$ ) [Mazzi 1901] which is the unit of measurement used by the bridge builders (Table 2):

Table 2. Conversion chart (Roman feet)

\begin{tabular}{|l|c|c|}
\multicolumn{1}{c}{ Element } & Meters & Roman feet (0.296 $\mathbf{~ m})$ \\
\hline Main arch (span) & 29.53 & $99.78 \simeq 100$ \\
\hline Main (height) & 11.60 & $39.20 \simeq 40$ \\
\hline Lateral arch (span) & 13.19 & $44.54 \simeq 45$ \\
\hline Lateral arch (height) & 6.59 & 22.27 \\
\hline Front (parapet?) & 1.31 & 4.45 \\
\hline
\end{tabular}

The metrological approach [Germano' 2020], with due margin of approximation, highlights the coincidence of the Roman measures with round numbers, the same as we would expect in a planned project. It is interesting to note that the 100 -feet measurement is an architectural constant of the Roman architecture, present in the contemporary Column of Trajan in Rome (113 CE), called "centenaria" for its height, but also in the Column of Marcus Aurelius. Similarly the 100-feet module appears in the diameters of many monuments such as mausoleums, public buildings, theater orchestras, bridges and many others, just to mention a few [Germano' 2020]. 


\subsection{Survey with drone technology and photogrammetry}

Following these considerations, we carried out an in situ verification of these observations, through various inspections and a survey campaign. The survey, made very difficult by the size of the bridge, the inaccessibility of the river and the dense vegetation that covers a large part of the structure, was made possible by the use of drone technology and then aerial photogrammetry.

The drone used was a DJI Mavic 2 Pro equipped with a high-resolution camera with $78.8^{\circ}$ shooting angle of $26.6 \mathrm{~mm}$ and 1/2.3" CMOS sensor of 12.7 Megapixel and GLONASS GPS system with vertical accuracy error of +/- $0.1 \mathrm{~m}$ and +/- $0.3 \mathrm{~m}$ horizontal.

We proceeded with an aerial photographic campaign in manual flight mode. Altogether, three series of photographs were shot. Two were made by flying around the monument at an altitude of 5 and 15 meters. The third flight was intended to take photographs with a top view shot at an altitude of 25 meters. The 5 meter shoot was made with a camera inclination of $0^{\circ}$, then with a view perpendicular to the building in order to reduce the aberrations during data processing, The one shot at 15 meters had a camera inclination of $45^{\circ}$ so that the photographs captured the intersection between the vertical and horizontal surfaces, In the shoot at 25 meters the camera was inclined downward to capture data from the upper part of the bridge, producing a total of 154 photographs with GSD (ground simple distance) of $4.55 \mathrm{~mm} /$ pix. During the shoots it was not necessary to use GCP (Ground Control Points) in order to subsequently scale the model, as the measurements were taken using the architectural elements present in the structure such as the widths of the spans and the width of its the extrados through direct survey operations and the use of laser level and laser rangefinder.

The photogrammetry operations were carried out with the help of Agisoft Metashape software, through which a dense point cloud was generated, on which a textured mesh composed of about 400k polygons and about 400k vertices was produced. The model (Fig. 3) was scaled according to the points detected in the campaign phases (Fig. 4-5-6).

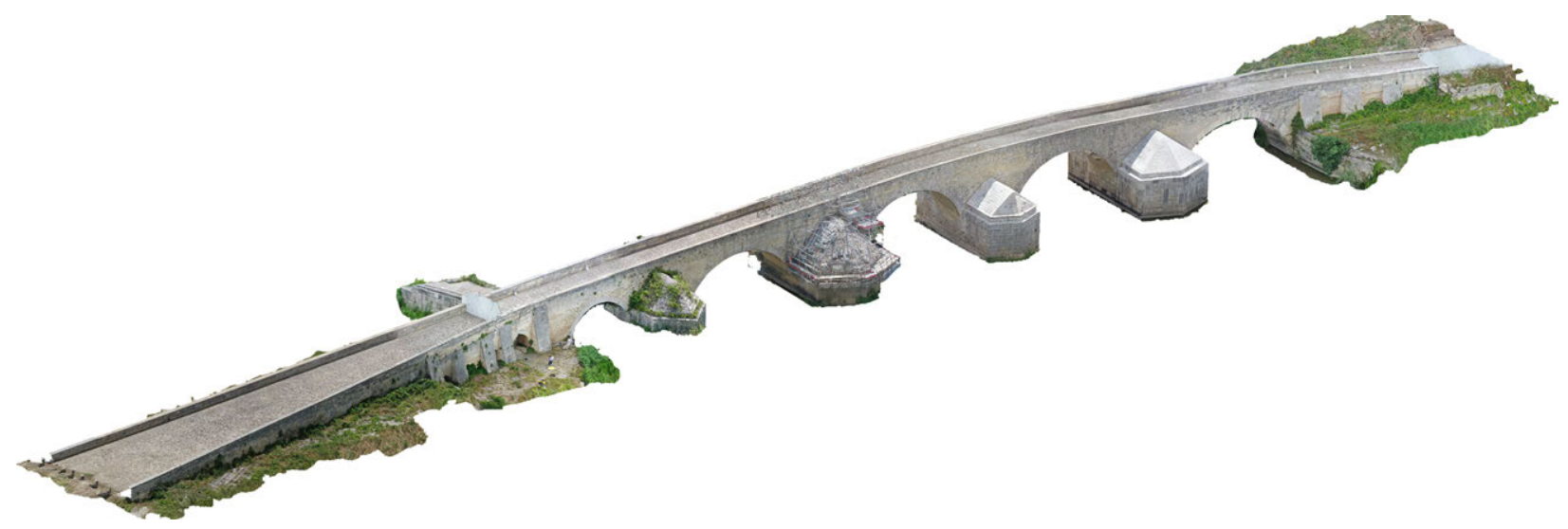

Figure 3. Photogrammetric restitution of the bridge. View from North Easth. 


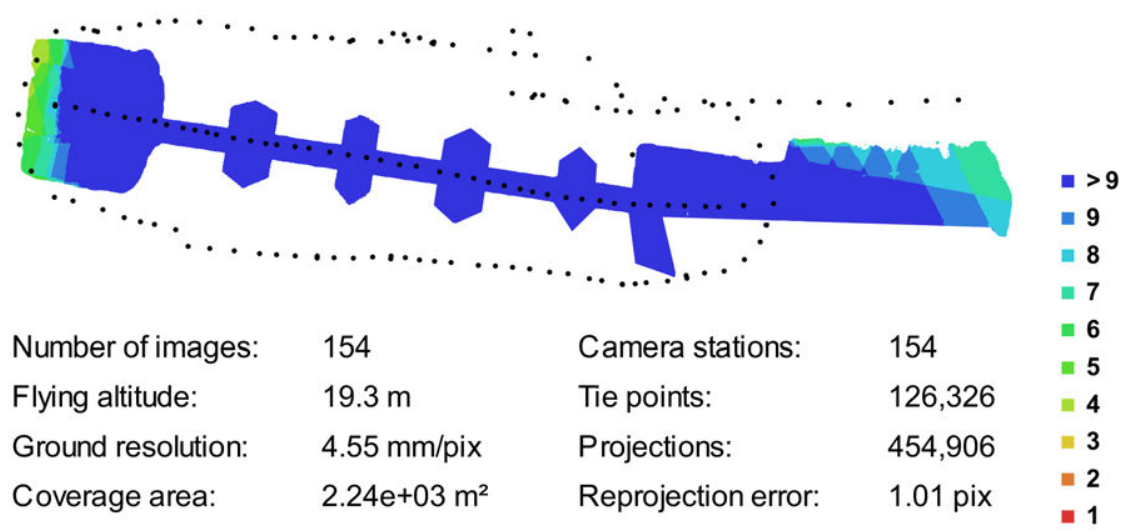

\begin{tabular}{|l|l|l|l|l|}
\hline Camera Model & Resolution & Focal Length & Pixel Size & Precalibrated \\
\hline L1D-20c $(10.26 \mathrm{~mm})$ & $5472 \times 3648$ & $10.26 \mathrm{~mm}$ & $2.41 \times 2.41 \mu \mathrm{m}$ & No \\
\hline
\end{tabular}

Figure 4. Survey report: Camera locations and image overlap.

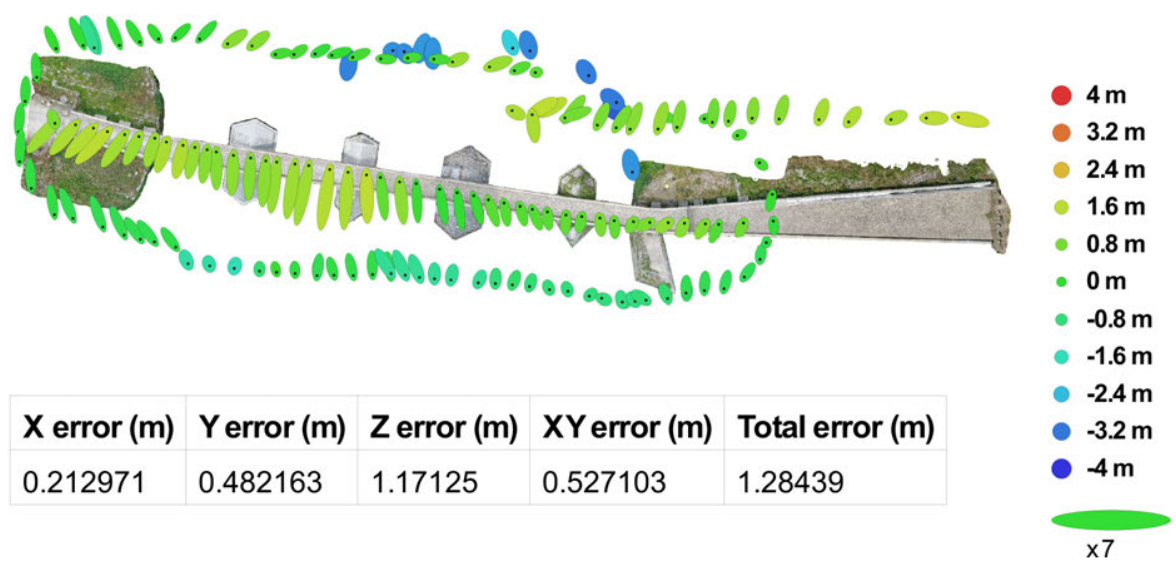

Figure 5. Camera locations and error estimates. Z error is represented by ellipse color. $X, Y$ errors are represented by ellipse shape. Estimated camera locations are marked with a black dot.

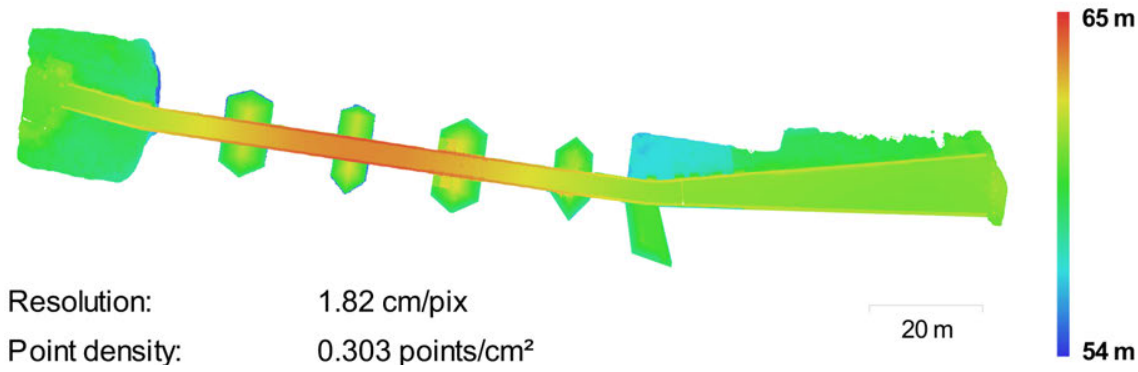

Figure 6. Reconstructed digital elevation model. 


\subsection{Data analysis and 3D reconstruction}

Once we recognized and classified the different USM, we identified the incline of the rows of blocks relative to the west side, which visibly differ from the grade of the current profile, thus assuming the probable original inclination (Fig.7).

This would be confirmed by the graphic reconstruction of the arches geometrically constructed on the basis of the dimensional data of the 1749 survey, providing a segmental arch typology [O'Connor 1994] if we assume the impost at the upper level of the buttresses (Fig. 8a).

The latter, with a triangular section to lighten the mass, in the first elevation drawings elaborated by Amato Poulet in 1756, following the reconstruction after the collapse show a stepped conformation (Fig. 8b). In the same elevation there is also an arched opening, in correspondence with the first spandrel from the east, which is probably the only evidence of a lightening window (Fig. 8c), almost always present in Roman bridges [Galliazzo 1995].

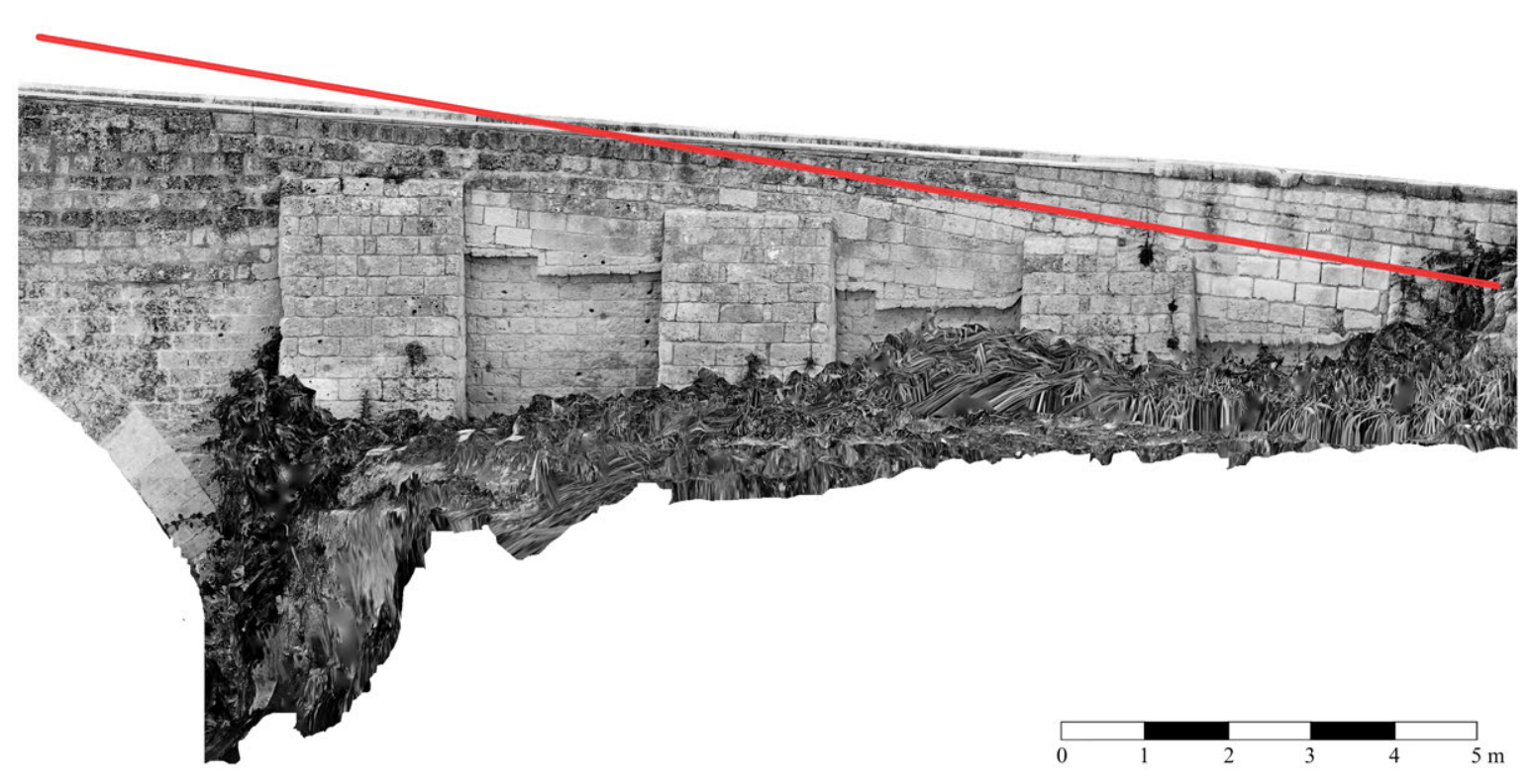

Figure 7. Northwest front of the bridge, abutment. The red line shows the probable original incline still identifiable in the grade of the rows of blocks. 

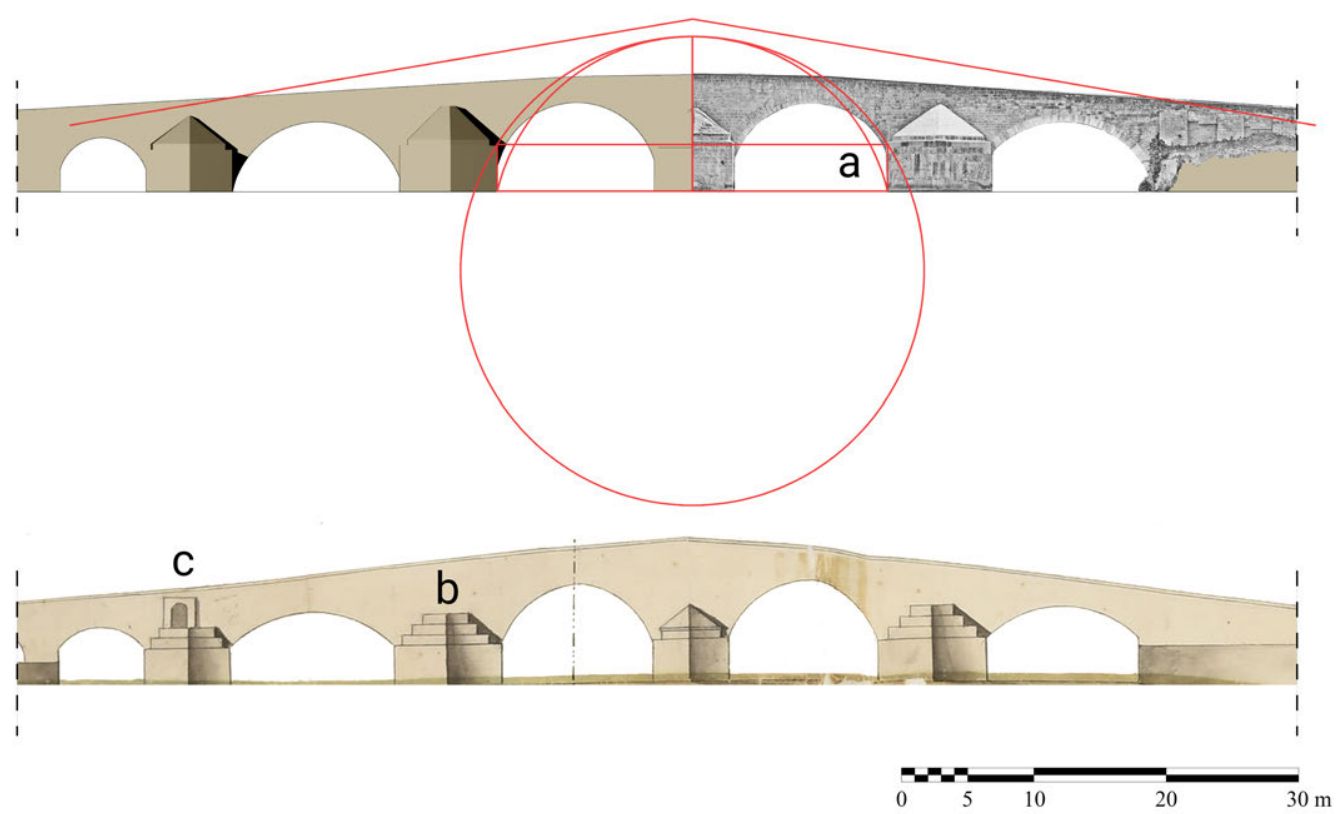

Figure 8. Upper, the bridge nowadays with the geometrical construction of the hypothesized shape. Lower, detail from the survey of Amato Poulet, 1756. (State Archives of Foggia, Italy)

Additional information comes from a comparison of the "front (parapet?)" measure of Delfino (5 Neapolitan palms, i.e., $131 \mathrm{~cm}$ ) with some inscribed slabs found in Cerignola [Ceraudo 2013] whose dimensions match perfectly, letting us imagine that it was set along the balustrade that delimited the passage on the bridge [Ferrari 2013]. This type of inscribed slab bore the inscription relating to the work, exalting its completion and was part of the construction program of the Via Traiana.

At least morphologically, the hypothesized profile is comparable with other well-preserved Roman bridges including the nearby bridge at Ascoli Satriano ( ${ }^{\text {nd }}$ century CE) and the Augustan Pont Julien in Bonnieux (France).

On the basis of all these elements we have elaborated a graphic reconstruction of the bridge in Roman times (Fig. 9).

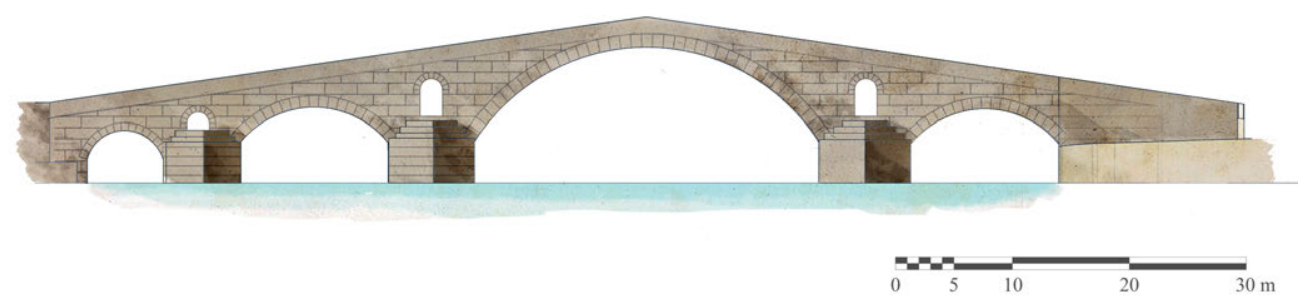

Figure 9. Graphical reconstruction of the bridge in Roman times (Germano Germanò). 
Starting from this, with the help of Rhinoceros modeling software, we developed a 3D model associating each USM and each construction phase to as a related layer, which can be updated at any time as research progresses (Fig. 10).

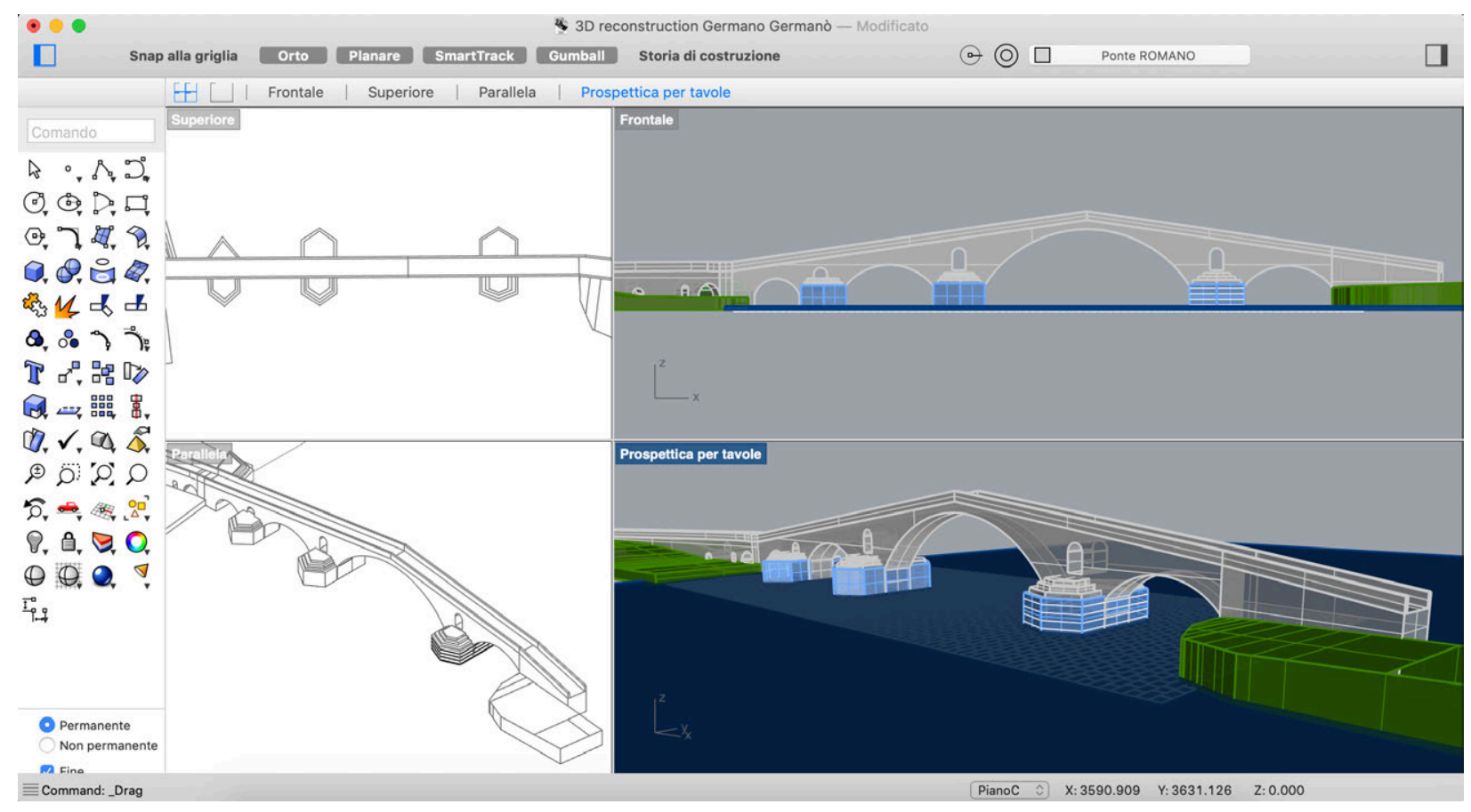

Figure 10. 3D model of the bridge and its reconstruction. Each layer is associated with a color, corresponding to a specific part of the structure or to a building phase.

At the end of the modeling phase, we illustrated the main construction phases (Fig. 11).

\section{CONCLUSIONS}

The advent of digital technologies, particularly aerophotogrammetric surveying and 3D modeling, have had a significant impact on archaeological research and constitute the squaring of the circle of one of its greatest limitations: to investigate without destroying, to preserve without losing. Until a few decades ago, the ability to reproduce the stratigraphic context of an archaeological site or architectural monument was the prerogative of institutions or professional technicians who could afford adequate and very often expensive instrumentation, while today research can also be carried out by individual researchers, provided they are equipped with the appropriate cognitive tools. The case study of the Ofanto bridge shows that modern technology not only supports archaeological research, but also makes it possible where it would otherwise be impossible or impractical, overcoming objective technical difficulties without compromising its quality. 

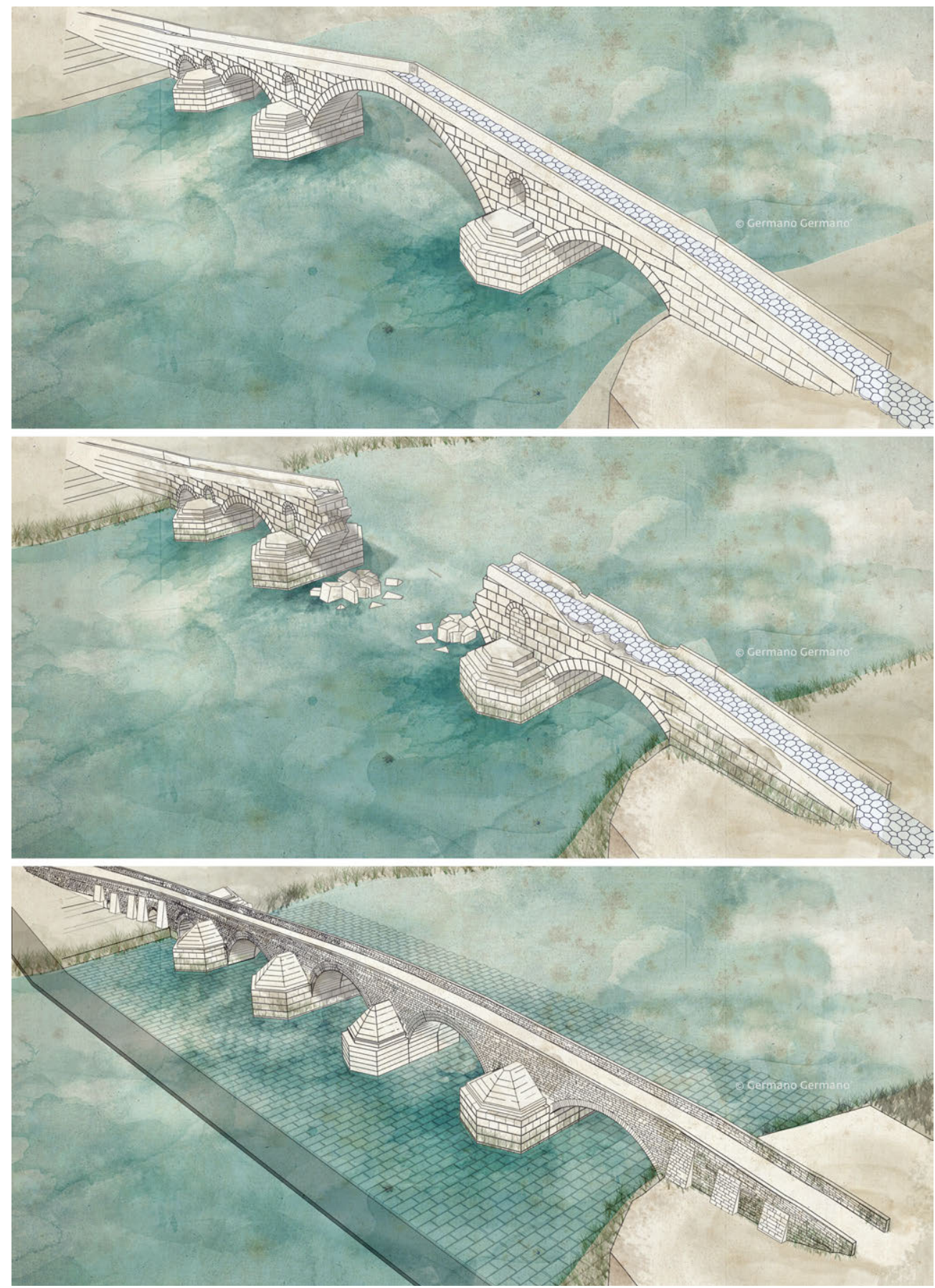

Figure 11. The main phases of the bridge: the Roman Age; the collapse; the bridge nowadays, showing the foundation platea ( $2^{\text {nd }}$ century CE) and the concrete walkway (20 th century CE). (Germano Germano'). 
The 3D reconstruction is the ideal outcome of this investigation, and its graphic representation is a powerful communication tool that is essential both for studies and for the valorization of cultural heritage, since it offers an immediately understandable vision that undoubtedly captures the attention of even those who are foreign to the subject, making them aware of the importance of conservation.

In particular, the reconstructive hypothesis of the bridge offers an evocative image that places it rightly among the monumental donkey-back bridges in Roman Italy. As reconstructed here, it must be very similar to the one seen and used by poets such as Horace, emperors on their way from rome to the East, shepherds who came to Puglia with their flocks, and humble folk of all kinds traveling up or down the Via Traiana. All of them must have found our bridge convenient to use and awesome to behold.

The advent of 3D modeling and photogrammetry have revolutionized the archaeological study of monuments, transforming the one-eyed Polyphemus into the all-seeing Argos.

\section{ACKNOWLEDGEMENTS}

The author gratefully acknowledges architect Remo Pavone for his contribution and support in the survey campaign and Ivan Ferrari for sharing his knowledge about Roman bridges.

\section{REFERENCES}

Raffaella Cassano. 1986. Recenti indagini archeologiche a Canosa. Profili della Daunia antica, $2^{\circ}$ Ciclo di conferenze sulle più recenti campagne di scavo. Foggia: 64-75.

Raffaella Cassano. 1992. Il ponte sull'Ofanto. In Raffaella Cassano (ed.) Principi, Imperatori, Vescovi, Duemila anni di Storia a Canosa, Venezia: Marsilio. 708-711.

Giuseppe Ceraudo. 2008. Via Gellia: una strada 'fantasma' in Puglia centrale. In "Studi di Antichità" vol.12, Galatina: Congedo, 187-203.

Giuseppe Ceraudo. 2013. A proposito delle lastre iscritte dei ponti della Via Traiana. In ATTA 22, Roma: L'Erma di Bretschneider, 143-153.

Marcella Chelotti, Vincenza Morizio and Marina Silvestrini. 1990. Le epigrafi romane di Canosa II. Bari: Edipuglia.

Elizabeth Fenthress, Caroline Goodson. 2003. Patricians, monks, and nuns: the abbey of S. Sebastiano, Alatri, During the Middle Ages. In Archeologia Medievale, XXX, 67-105.

Ivan Ferrari. 2013. I ponti romani della Via Traiana (unpublished doctoral dissertation). Università del Salento. Lecce.

Vittorio Galliazzo. 1995. I ponti romani. Treviso: Canova.

Germano Germano', 2020. The Roman bridge of Canosa di Puglia: a metrological approach. IMEKO TC-4 International Conference on Metrology for Archaeology and Cultural Heritage, Trento, Italy, October 22-24, 2020, 605-610.

Pasquale Ieva. 2015. La sepultura di Re Boamundo in una inedita brieve descrittione tardocinquecentesca. In Cosimo Damiano Fonseca and Pasquale Ieva (eds.) Unde boat mundus quanti fuerit Boamundus: Boemondo I di Altavilla, un normanno tra Occidente e Oriente: atti del 
Convegno internazionale di studio per il IX centenario della morte, Canosa di Puglia, 5-6-7 maggio 2011. Bari: Convegni. Società di storia patria per la Apulia, 301-335.

Angelo Mazzi. 1901. Nota metrologica. In Archivio Storico Lombardo. Milano: Società Storica Lombarda, 354.

John McCarthy. 2014. Multi-image photogrammetry as a practical tool for cultural heritage survey and community engagement. In Journal of Archaeological Science, Volume 43, 175-185.

Colin O'Connor. 1994. Development in Roman stone arch bridges. In Endeavour, Volume 18, Issue 4, 157-162.

Roberto Parenti. 1988. Le tecniche di documentazione per una lettura stratigrafica dell'elevato. In Riccardo Francovich and Roberto Parenti (eds.), Archeologia e restauro dei monumenti. Firenze: All'Insegna del Giglio, 249-279.

Roberto Parenti. 1988. Sulle possibilità di datazione e di classificazione delle murature. In Riccardo Francovich and Roberto Parenti (eds.), Archeologia e restauro dei monumenti. Firenze: All'Insegna del Giglio, 280-304.

Catello Salvati. 1970. Misure e pesi nella documentazione storica dell'Italia del Mezzogiorno. Napoli: L'arte tipografica, 34-35.

Efstratios Stylianidis. 2020. Photogrammetric Survey for the Recording and Documentation of Historic Buildings. Cham, Springer.

Maria Rosaria Tritto. 2005. I restauri settecenteschi del ponte romano di Canosa di Puglia. In Liana Bertoldi Lenoci (ed.). Canosa. Ricerche Storiche 2004, Fasano: Schena Editore, 71-100.

Received March 2021; revised May 2021; accepted May 2021. 